\title{
Living Values Based Interactive Multimedia in Civic Education Learning
}

\author{
Kokom Komalasari
}

Prof., Universitas Pendidikan Indonesia, Indonesia, kokom@upi.edu

\section{Rahmat}

Senior Lecturer, Universitas Pendidikan Indonesia, Indonesia, rahmat003@upi.edu

This study seeks to develop and validate a model of living values-based interactive multimedia in Civic Education learning. A Research and Development approach was employed. Data were gathered through observations, interviews, document study, focus group discussions, and questionnaires. Data were analyzed by way of interactive models and a descriptive quantitative analysis. The subjects were students and teachers at junior high schools and senior high schools in Bandung, Indonesia. Results reveal that: i) the model conceptually integrates living values and the principles of living values education into interactive multimedia with especial attention to core competencies and basic competencies of Civic Education according to the 2013 curriculum of Indonesia, the principles of scientific learning, and the principles of interactive multimedia development; ii) the framework of the model consists of motivation, title, menu, CC-BC (Core Competencies and Basic Competencies) and learning objectives, concept maps, material contents with multimedia variations, motivational/reflection videos, VCT Lists, and Quizzes; iii) the results of the validation indicate that most of the components of contents, presentation, multimedia principles, and the initial product of the model are considered fairly good. Most students very positively perceived the use of interactive multimedia in Civic Education learning for character development.

Keywords: interactive multimedia, living values, learning, civic education, multimedia

\section{INTRODUCTION}

The subject of civic education in Indonesia is a subject that carries out the mission of educating the life of the Indonesian nation through "value-based education" and serves as the means of nation and character building. Civic education is expected to contribute to solving the national problem of the shifting of ethical values, the waning awareness of the cultural values, the threat of national disintegration, the weakening of selfreliance, as well as the problem of young generation demoralization as indicated by the

Citation: Komalasari, K., \& Rahmat (2019). Living Values Based Interactive Multimedia in Civic Education Learning. International Journal of Instruction, 12(1), 113-126. https://doi.org/10.29333/iji.2019.1218a 
diminishing application of the values of life (Ministry of National Education, 2010; Megawangi, 2004; Komalasari \& Saripudin, 2015; Komalasari \& Saripudin, 2018).

As civic education in practice emphasizes more on the mastery of the subject matter, the development of attitudes and skills for the character formation of the learners has not received ample attention as it should be. This is because the integration process of character development in civic learning has not been optimal, including the components of learning media as one of the instrumental inputs. Learning media is a means of education that can be used as an intermediary in the learning process to enhance the effectiveness and efficiency in achieving the goal of learning; that is behavior change (Komalasari, 2010: Usman, 2002; Munadi, 2008, Komalasari \& Sapriya, 2016).

The $21^{\text {st }}$ century is known as the era of globalization and information-communication technology (ICT). The rapid progress of ICT offers new conveniences of learning, giving rise to the shift of learning orientation from outside-guided to self-guided and from knowledge-as-possession to knowledge-as-construction (Priyanto, 2009). Thus, an effective learning media in this ICT era is interactive multimedia.

Multimedia is an integration of two or more integrated media formats such as texts, images, graphics, sounds, animations, and videos to feed information into computer systems. This integration as a whole displays information, messages, or lesson contents. Through these combined media, learning activities are rendered more interactive and reflect everyday life experience (Arsyad, 2009; Vaughan, 2004; Heinich et al., 2005). Interactive multimedia combines and synchronizes media of all types consisting of texts, graphics, audios, videos, animations and interactivity tailored to allow people to access various forms of media to render a program more meaningful to the users. Interactive multimedia is equipped with a controller for users, so they can pick subsequent activities of their choice (Green \& Brown, 2002; Sutopo, 2003). Interactive multimedia is the use of a computer to blend texts, graphics, audio, moving images (video and animation) into a single entity with proper links and tools to enable users of multimedia to navigate, interact, create, and communicate" (Hofstetter, 2001; Mayer, 2009).

In general, learning media in civic subject in school today is too plain in presentation, not in the form of interactive multimedia. It presents mostly teaching materials of the concepts and principles of knowledge and less educate the learners how to act and to behave according to the concepts and principles of knowledge in everyday life (Komalasari \& Saripudin, 2017a).

Thus, the empirical question is how to reconstruct civic learning media to be better suit the demands of ICT advancements, and also to be able to shape the character of the students. First, learning media should be ICT-based in accordance with the demands of the 21 st century. Second, media are living values-based, meaning that they are based on the basic values of life so that they can be more easily internalized and implemented (Saripudin \& Komalasari, 2015). Third, media must be interactive, which can enable the learners to involve in a self-regulated learning. Fourth, media involve the aspects of "knowing the good, desiring the good/loving the good and acting the good" (Lickona, 
1991). Fifth, media should be contextual in the sense that they link the material with its application in real life.

All of these characteristics must be integrated into civic learning media through a model of living values-based interactive multimedia. The interactive multimedia at hand is a computer-based learning multimedia that interactively presents civic teaching materials and incorporates the basic values of life of the students (Komalasari \& Saripudin, 2017b). Research in this vein is, therefore, a must.

On the basis of the research and development approach, this study seeks to produce a model of living values-based interactive multimedia for civic learning that is assumed to be able to effectively shape the character of the learners. The research questions under study are as follows:

1. What is the conceptual model of living values-based interactive multimedia in Civic Education learning for character development?

2. What is the framework of living values-based interactive multimedia in Civic Education learning for character development?

3. What is the validation result of expert and practitioners on living values-based interactive multimedia in Civic Education learning for character development?

\section{METHOD}

Method

As aforementioned, this study uses a Research and Development approach. The procedures under this approach, according to Borg \& Gall (1989), basically comprise two main objectives: (i) developing the product, and (ii) testing the effectiveness of the product in achieving the goal. The first objective is called a development function, while the second is called validation. Thus, the concept of research and development is more properly defined as a development effort coupled with validation.

Process

Borg and Gall's (1989) research and development framework was utilized, which consists of ten steps. In the context of this study, only step one to seven were used namely: (1) Research and information collecting, (2) Planning, (3) Developing a preliminary form of product (living values-based interactive multimedia in civic learning), (4) Preliminary field testing, (5) Main product revision, (6) Main field testing; and (7) Operational product revision 
Table 1

The Process of Research

\begin{tabular}{|c|c|c|}
\hline No & Research Procedures & Descriptions \\
\hline 1 & $\begin{array}{l}\text { Research and } \\
\text { information collecting }\end{array}$ & $\begin{array}{l}\text { Literature studies related to the issues studied, and preparation } \\
\text { for formulating the research framework. }\end{array}$ \\
\hline 2 & Planning & $\begin{array}{l}\text { Formulate skills and expertise related to the making of living } \\
\text { values based interactive multimedia in civic learning, to } \\
\text { determine the objectives to be achieved at each stage, and to } \\
\text { conduct feasibility studies in a limited way. }\end{array}$ \\
\hline 3 & $\begin{array}{l}\text { Developing } \\
\text { preliminary form of } \\
\text { product }\end{array}$ & $\begin{array}{l}\text { Develop the initial form of the product to be generated the } \\
\text { initial product of living values based interactive multimedia in } \\
\text { civic learning. Included in this step is the preparation of } \\
\text { supporting components, preparing guidelines and manuals, and } \\
\text { evaluating the feasibility of supporting tools. }\end{array}$ \\
\hline 4 & $\begin{array}{l}\text { Preliminary field } \\
\text { testing }\end{array}$ & $\begin{array}{l}\text { Requests input from experts and practitioners, and conducts } \\
\text { initial product piloting of living values based interactive } \\
\text { multimedia in civic learning on a limited scale }\end{array}$ \\
\hline 5 & Main product revision & $\begin{array}{l}\text { Make improvements to the initial products of living values } \\
\text { based interactive multimedia in civic learning that has been } \\
\text { produced }\end{array}$ \\
\hline 6 & Main field testing & $\begin{array}{l}\text { Create living values based interactive multimedia in civic } \\
\text { learning and perform expert validation (content expert, } \\
\text { learning media and interactive multimedia). }\end{array}$ \\
\hline 7. & $\begin{array}{l}\text { Operational product } \\
\text { revision }\end{array}$ & $\begin{array}{l}\text { Making improvements to the validation results, so that the } \\
\text { product of living values based interactive multimedia in civic } \\
\text { learning turns to be a model design. }\end{array}$ \\
\hline
\end{tabular}

\section{Participants}

The research took place in Bandung, West Java, Indonesia. Participants in the study were students of Junior High School (SMP) and Senior High School (SMA), teachers of Citizenship Education as practitioners, and lecturers who are experts in materials and multimedia civic education. More specifically, the participants of the study were students of SMP 7 Bandung, SMP 12 Bandung, SMP 1 Lembang, SMA 2 Bandung, SMA Labschool Indonesia University of Education, and SMA Lembang with 60 students participating from each school, amounting to 360 students. For the purposes of model development and validation, the research involved four experts in the field of learning multimedia and content material of civic education and two teachers as the representative of each school.

\section{Data Collection Tools}

While qualitative data were collected through observation, documentation, and interview, quantitative ones were collected merely through questionnaires. Observations, interviews, focus group discussions and documentation were used to develop the model of living values-based interactive multimedia in Civic Education learning. Questionnaires were used to collect validation data on models from experts and 
practitioners and students' responses to the use of the model of living valuesbased interactive multimedia in civic education learning.

Data analysis

Qualitative data were analyzed with an interactive analysis model covering data collection, data reduction, data presentation and conclusion/verification (Miles \& Huberman, 2014). It was equipped with a descriptive quantitative analysis using percentages (Creswell, 2012).

\section{FINDINGS}

The conceptual model of living values-based interactive multimedia in civic learning for character development

Conceptually speaking, living values-based interactive multimedia for civic learning incorporates living values and the principles of living values education into interactive multimedia by heeding the principles of scientific learning (a learning demand in the 2013 Curriculum), and Core Competencies and Basic Competencies as prescribed in the Curriculum, the principles in developing interactive multimedia, language and legibility, and presentation (display).

Among the principles in developing living values-based interactive multimedia are as follows (Komalasari \& Saripudin, 2017b):

a. Developing such values of life as Peace, Respect, Love, Responsibility, Happiness, Cooperation, Honesty, Humility, Tolerance, Modesty, Freedom and Unity.

b. Developing the principles of living values education (Tillman, 2004) that includes gathering points of reflection, having a broad imagination, exercising relaxation and focus, expressing the creation of art, developing social skills, developing cognitive awareness about justice, promoting social harmony, and collecting cultural values.

c. Applying the principles of learning in the development of interactive multimedia, which includes readiness, motivation, using the tool of total attention getter (illustrations, colorful images, varied handwriting), learners' active participation, repetition, feedback, social cognitive interaction vision, authentic assessment, reflecting, life skill, observation, questioning, gathering information, analyzing, and communicating the project of learning model, problem solving, and discovery.

d. Developing Core Competencies and Basic Competencies in the curriculum of 2013 to impart knowledge (as a core material that learners should know and understand), skills (the practical ability derived from knowledge that can be used to face problems in life), and attitudes (the characters that every learner should have to support the effectiveness of participation in life).

e. Applying the principles of interactive multimedia development 
The concept of interactive multimedia in this study is an interactivity that combines and synergizes all forms of media i.e. text, graphics, audio, video, animation and interactivity (Green \& Brown, 2002: 2-6). All these types of media (text, image/photo/poster, animation, video, and VCT-List) were put together into in a single power-point material. Each media has the following contents and functions:

1) The texts consist of and present facts, data, concepts, principles, procedures, and values-moral-norms (character-values of life)

2) Images, photos, posters, and comics are used as stimulus to explain learning materials and to clarify the values

3) Graphics, charts, and diagrams are used to present data on issues/problems/phenomena that exist in the real life.

4) Animations in the form of audio-visual media containing eye catching, value-rich cartoons contain a dilemma over a value in order to stimulate the learners to think, to clarify, to reflect and to apply the life values.

5) Videos in the form of audio-visual media contain a film about a phenomenon in everyday life that motivates the learners to apply the values of life.

6) The VCT List contains a table of List of Continuum Symptoms that presents a behavior statement and how to materialize in everyday life, along with the rationale of the application of that behavior.

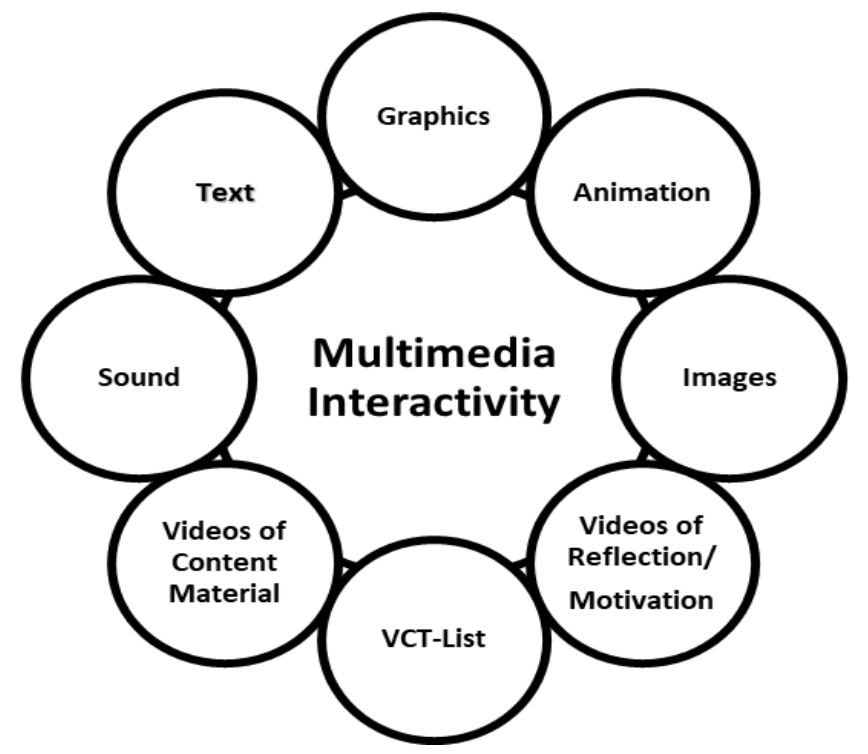

Figure 1

Interactivity as a Multimedia Application Center (Munir, 2012; Komalasari and Saripudin, 2017b) 


\section{The Framework of Living values-based interactive multimedia}

Based on the results of focus group discussions with experts in multimedia learning and content material of Civic Education, and practitioners in the field (teachers of Civic Education), an organization of living values-based interactive multimedia is schematized as follows.

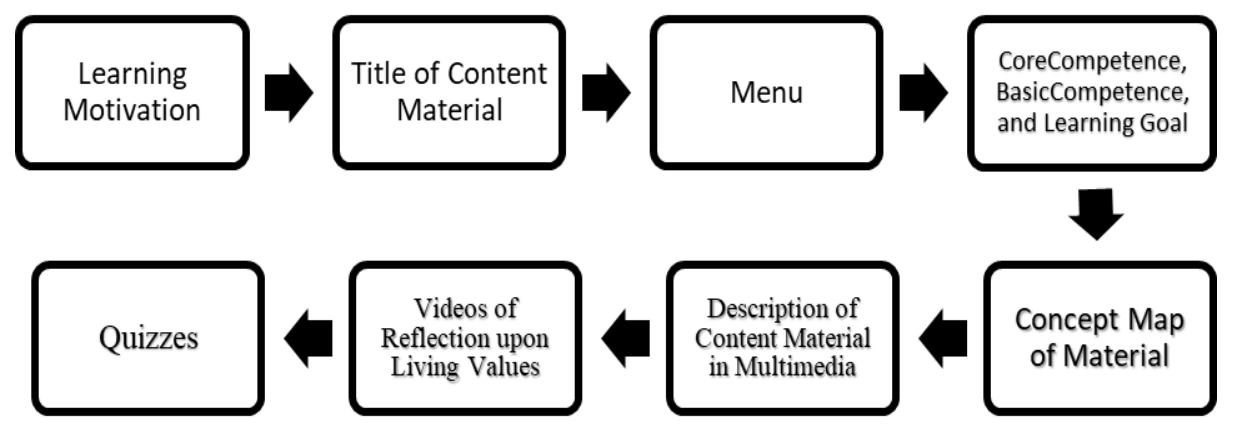

Figure 2

The Framework of Value-based Interactive Multimedia

As seen in Figure 2, a value-based interactive multimedia in Civic Education learning should include the following components.

a. Learning Motivation-delivered through the presentation of wise words or advice to study earnestly. For example: "Let's learn, knowledge is a valuable investment for your future", or a variety of "motivational videos" to boost students' learning motivation.

b. The title of the material-developed from the Basic Competencies of Civic Education in the 2013 Curriculum.

c. The menu - the aspects in interactive multimedia that can be selected and tracked by the students based on its order or the needs of students.

d. Core Competencies (CC), Basic Competencies (BC), and Learning Objectives. CC and $\mathrm{BC}$ for Civic Education are taken from the 2013 Curriculum, while the learning objectives are formulated by the teachers with reference to $\mathrm{CC}$ and $\mathrm{BC}$. The learning objectives guide the students to know what to accomplish in the learning they follow.

e. Concept maps - consisting of the mapping of material concepts to be learned by the students. Students can choose and browse which material they will learn.

f. Learning materials - containing descriptions of each concept map that is presented in the beginning. The material is presented in a descriptive-interactive description with pictures and can also be in a video of material description, comic, story, and etc. 
g. A reflection video-rich with values in accordance with the objectives and the learning materials. The reflection video is intended to dig, to clarify, to internalize, and to apply the values in behavioral patterns. Therefore, the reflection video must be followed by the students' self-reflection and the students making an action plan of what they will do in their daily life.

h. Quizzes - a number of questions with multiple choices that should be selected by the students. The students' answer can be responded immediately in terms of correctness, thus their understanding of the material can be easily identifiable. If the answer is incorrect, the student can repeat the question until he/she finds the correct answer. Quizzes are intended as review sessions to see how well the students understand the material.

The Validation Result of Expert and Practitioner to Living Values-Based Interactive Multimedia

The initial product of living values-based interactive multimedia was carefully validated by the experts and practitioners in the field. Based on the validation of four experts (the experts of Civic Education) and four practitioners (Civic Education teachers) on the initial product, the results are illustrated in the following table. 
Table 1

The Result of Expert and Practitioners Validation on Living Values-Based Interactive Multimedia

\begin{tabular}{|c|c|c|c|c|c|c|}
\hline \multirow[t]{2}{*}{ No } & \multirow{2}{*}{$\begin{array}{l}\text { The } \\
\text { assessed } \\
\text { component }\end{array}$} & \multirow[t]{2}{*}{ Rated aspect } & \multicolumn{3}{|c|}{ Validation Results $(\mathrm{N}=12)$} & \multirow[b]{2}{*}{$\begin{array}{l}\text { Very Poor } \\
(\%)\end{array}$} \\
\hline & & & $\begin{array}{l}\text { Very Gooc } \\
(\%)\end{array}$ & $\begin{array}{l}\text { Good } \\
(\%)\end{array}$ & $\begin{array}{r}\text { Poor } \\
(\%)\end{array}$ & \\
\hline \multirow[t]{7}{*}{ A } & \multirow[t]{7}{*}{$\begin{array}{l}\text { Feasibility } \\
\text { of Content }\end{array}$} & $\begin{array}{l}\text { The conformity of Material Description } \\
\text { with } \mathrm{CC} \text { and } \mathrm{BC}\end{array}$ & 90 & 10 & 0 & 0 \\
\hline & & Material Accuracy & 50 & 30 & 20 & 0 \\
\hline & & Recency & 40 & 40 & 20 & 0 \\
\hline & & Growing the spiritual and social attitudes & 30 & 50 & 20 & 0 \\
\hline & & Developing the values of life & 60 & 30 & 10 & 0 \\
\hline & & Developing the knowledge insight & 50 & 30 & 20 & 10 \\
\hline & & Developing the practical skills & 30 & 40 & 20 & 0 \\
\hline \multicolumn{3}{|c|}{ Average Value of Component A } & 50.0 & 32.9 & 15.7 & 1.4 \\
\hline \multirow[t]{3}{*}{ B } & \multirow[t]{3}{*}{ Presentation } & $\begin{array}{l}\text { Presentation Techniques (systematic, } \\
\text { consistent, suitability of illustrations with } \\
\text { material, and interesting) }\end{array}$ & 40 & 40 & 10 & 10 \\
\hline & & Presentation of Scientific Learning & 70 & 20 & 10 & 0 \\
\hline & & $\begin{array}{l}\text { Presentation of the principles of Living } \\
\text { Values Education }\end{array}$ & 40 & 30 & 30 & 0 \\
\hline \multicolumn{3}{|c|}{ Average Value of Component B } & 50.0 & 30.0 & 16.7 & 3.3 \\
\hline \multirow[t]{6}{*}{$\bar{C}$} & \multirow[t]{6}{*}{$\begin{array}{l}\text { Multimedia } \\
\text { Principles }\end{array}$} & $\begin{array}{l}\text { Text (containing facts, data, concepts, } \\
\text { principles, procedures, and values of life }\end{array}$ & 60 & 20 & 5 & 5 \\
\hline & & $\begin{array}{l}\text { Pictures, photos, posters, comics (as } \\
\text { stimulus to clarify materials and values) }\end{array}$ & 50 & 30 & 20 & 10 \\
\hline & & $\begin{array}{l}\text { Graphics, charts, } \\
\text { diagrams (presenting and } \\
\text { issues/problems/phenomena in the real } \\
\text { life) }\end{array}$ & 60 & 20 & 10 & 10 \\
\hline & & $\begin{array}{l}\text { Eye catching, value-rich animations } \\
\text { (containing a dilemma of value, and } \\
\text { provide the stimulus for the students to } \\
\text { think, to clarify, to reflect, and to apply } \\
\text { the values of life) }\end{array}$ & 50 & 20 & 10 & 10 \\
\hline & & $\begin{array}{l}\text { Videos (a movie about a life phenomenon } \\
\text { to motivate the application of the values } \\
\text { of life) }\end{array}$ & 50 & 20 & 20 & 0 \\
\hline & & $\begin{array}{l}\text { VCT List (a behavior statement, the } \\
\text { frequency of } \\
\text { with its rationale) }\end{array}$ & 40 & 30 & 20 & 10 \\
\hline \multicolumn{3}{|c|}{ Average Value of Component C } & 51.8 & 23.4 & 14.2 & 7.6 \\
\hline \multicolumn{3}{|c|}{ Average of Total Value } & 50.6 & 28.8 & 15.5 & 4.2 \\
\hline
\end{tabular}

The table of validation above shows that the majority of components of contents, presentation and principles of multimedia on the initial product of living valuesbased interactive multimedia are considered sufficient. On the aspect of the content, the development of the learners' skills and the development of socio-spiritual attitudes must be improved. On the aspect of presentation, an area of improvement is its presentation techniques so that it is more interesting and more associated with the values of life, its 
format should be consistent and attractive, and its illustrations should describe the concept of material and the values of life. As for multimedia, to be improved is the VCT List containing a table of List of Continuum Symptoms that presents behavior statements and how to apply the frequency of behavior in daily life, along with the rationale of the behavior application.

Students as the users of this living values-based multimedia provide specific responses based on the questionnaires, as can be seen in the following table 2 .

Table 2

Student Responses to the Use of Living Values-Based Interactive Multimedia in Civic Learning

\begin{tabular}{|c|c|c|c|c|c|c|c|c|}
\hline \multirow{2}{*}{ No Rated aspect } & \multicolumn{4}{|c|}{$\begin{array}{l}\text { Junior high school Students } \\
\qquad(\mathrm{N}=180) \\
\end{array}$} & \multicolumn{4}{|c|}{$\begin{array}{l}\text { Senior high school student } \\
(\mathrm{N}=180)\end{array}$} \\
\hline & $\begin{array}{l}\mathrm{VG} \\
(\%)\end{array}$ & $\begin{array}{c}\mathrm{G} \\
(\%)\end{array}$ & $\begin{array}{l}\mathrm{P} \\
(\%)\end{array}$ & $\begin{array}{l}\mathrm{VP} \\
(\%)\end{array}$ & $\begin{array}{l}\mathrm{VG} \\
(\%)\end{array}$ & $\begin{array}{c}\mathrm{G} \\
(\%)\end{array}$ & $\begin{array}{l}\mathrm{P} \\
(\%)\end{array}$ & $\begin{array}{l}\mathrm{VP} \\
(\%) \\
\end{array}$ \\
\hline $\begin{array}{l}\text { 1. The current media is better than } \\
\text { the learning media previously used. }\end{array}$ & 80 & 15 & 3 & 2 & 82 & 10 & 7 & 1 \\
\hline $\begin{array}{l}\text { 2. The current media is } \\
\text { more communication and information } \\
\text { technology-based }\end{array}$ & 84 & 11 & 5 & 0 & 85 & 9 & 5 & 1 \\
\hline $\begin{array}{l}\text { 3. The current media uses varied } \\
\text { instructional media as a whole }\end{array}$ & 72 & 23 & 4 & 1 & 76 & 20 & 3 & 1 \\
\hline $\begin{array}{l}\text { 4. The current media is in accordance with } \\
\text { the learning objectives and materials }\end{array}$ & 71 & 23 & 4 & 2 & 70 & 25 & 4 & 1 \\
\hline $\begin{array}{l}\text { 5. The presented learning material is more } \\
\text { systematic and directed. }\end{array}$ & 78 & 20 & 2 & 0 & 80 & 16 & 4 & 0 \\
\hline $\begin{array}{l}\text { 6. The current media integrates a variety of } \\
\text { learning methods. }\end{array}$ & 72 & 18 & 5 & 5 & 73 & 23 & 2 & 2 \\
\hline $\begin{array}{l}\text { 7. The current media measures the } \\
\text { achievement of learning goals } \\
\text { (comprehension, attitudes, and skills) }\end{array}$ & 65 & 33 & 2 & 0 & 63 & 34 & 3 & 0 \\
\hline $\begin{array}{l}\text { 8. The current media provides feedbacks on } \\
\text { the achievement of learning objectives }\end{array}$ & 60 & 25 & 8 & 7 & 64 & 24 & 8 & 4 \\
\hline $\begin{array}{l}\text { 9. The current media improves the } \\
\text { comprehension of the subject matter }\end{array}$ & 81 & 26 & 3 & 0 & 85 & 14 & 1 & 0 \\
\hline $\begin{array}{l}\text { 10. The current media develops the values } \\
\text { that exist in a real daily life }\end{array}$ & 79 & 21 & 0 & 0 & 75 & 15 & 10 & 0 \\
\hline $\begin{array}{l}11 \text {. The current media is interesting and } \\
\text { boosts the motivation to learn }\end{array}$ & 85 & 15 & 0 & 0 & 87 & 13 & 0 & 0 \\
\hline $\begin{array}{l}\text { 12. The current media enhances the } \\
\text { meaningfulness of the learning process }\end{array}$ & 79 & 19 & 1 & 1 & 75 & 16 & 8 & 1 \\
\hline $\begin{array}{l}\text { 13. The current media develops learning } \\
\text { independence }\end{array}$ & 75 & 15 & 8 & 2 & 73 & 18 & 8 & 1 \\
\hline $\begin{array}{l}\text { 14. The current media encourages more } \\
\text { active and interactive learning activities. }\end{array}$ & 78 & 17 & 5 & 0 & 75 & 19 & 4 & 2 \\
\hline $\begin{array}{l}\text { 15. The students are able to reflect on the } \\
\text { application of life values. }\end{array}$ & 85 & 15 & 0 & 0 & 82 & 17 & 1 & 0 \\
\hline Average Value & 76.2 & 19.4 & 3.2 & 1,2 & 76.3 & 18.5 & 4.3 & 0.9 \\
\hline
\end{tabular}

Description: $\mathrm{VG}=$ Very Good; $\mathrm{G}=$ Good; $\mathrm{P}=$ Poor; and VP = Very Poor

Table 2 shows that $76.2 \%$ of junior high school students and $76.3 \%$ of senior high school students respond very well to the use of interactive multimedia in civic 
learning. Most junior and senior high school students consider that the interactive multimedia used by teachers is different from the previous one, so it is an innovative learning medium. The students see the differences in terms of information and communication technology-based media diversity that are displayed interactively, and the clarification and reflection of the life values. In addition, most students are interested, motivated, and more understand the material presented through interactive multimedia. Multimedia activates and develops students' independence in civic learning. However, the thing that needs to develop further in multimedia learning is the assessment and feedback on comprehension, attitude, and skill as a whole and comprehensive, so that the assessment is not enough with only quizzes which relatively measure more on the comprehension, but also attitude assessment in form of attitude and skill scale through performance test and product assessment.

\section{DISCUSSION}

An overview of living values-based interactive Multimedia model in Civic Education for the development of student character can be analyzed from the following points.

First, interactive multimedia as a computer-based multimedia becomes increasingly important in the digital era, because multimedia systems consisting of components of the media (text, images, graphics, animation, audio and video) are designed to complement each other so that it becomes a useful and efficient system, in which the whole is greater than the sum of its part) (Hackbarth, S, 1996). Interactive multimedia meets the demands of learning in the digital era which is characterized by advancement in information and communication technology. In addition, the use of interactive multimedia by teachers in learning in accordance with the requirement of the development of teacher pedagogic competence as it is required in the implementation of the 2013 Curriculum in Indonesia.

Second, the living values-based interactive multimedia integrates the life values and the principles of life value education in interactive multimedia, so that interactive learning multimedia should explore and develop personal core values and social values of the students, such as Peace, Honor, Love, Responsibility, Happiness, Cooperation, Honesty, Humility, Tolerance, Modesty, Freedom and Unity. Those values are explored through the principles of living values education; namely one of learning model developments derived from character education that emphasizes fun learning principles. These activities of value education have several indicators in each activity as stated by Tillman (2004), namely: 1) Gathering the points of reflection; 2) Having a broad imagination; 3) Exercising relaxation and focus; 4) Expressing art; 5) Developing social skills; 6) Developing cognitive awareness about justice; 7) Developing social harmony; and 8) Incorporating cultural values. Thus, value-based interactive multimedia can present knowledge, skills, and attitudes. Values can be presented in a variety of interactive multimedia, for example through a character video or a motivational video. However, it is not enough, the teacher should facilitate the students to clarify the values in the character/motivational videos and reflect on how to apply it in daily life in the family, campus, community, nation and country (Komalasari \& Saripudin, 2017b). 
Third, the use of interactive learning multimedia is comprehensible for the students because it enhances self-learning process and active role of students. In addition, interactive multimedia can stimulate learning process that takes place outside the classroom (Latuheru, 1988). Computer-based learning multimedia can provide answers to a form of learning that used to be traditionally unenforceable. This is reinforced by Agnew et al.'s opinion (1996) that whereas some applications use computers merely to facilitate activities that students could perform in other ways, multimedia uses computers to help students perform activities that were previously impossible. A word processor makes a typewriter that can change and reforms pages, and a spreadsheet makes a sheet of squared paper that recalculates numbers, so it's faster. However, the links that are in the form of a key part of multimedia projects allow users to interact with information in new ways.

Fourth, in developing and selecting living values-based interactive multimedia as an integral part of the overall learning system, teachers theoretically need to select media in order to have a specification objective, a specification of content, a determination of strategy, and allocation of time (Gerlach \& Ely, 1980). Practically, the teacher should consider: 1) Demonstration: whether the media can be used as a tool to demonstrate a concept, tool, object, usability, user manual and etc.; 2) Familiarity: they are already accustomed to using the media, they think that they have mastered the media; 3) Clarity: The media more clarifies the message of learning and provides a more concrete explanation; 4) Active learning: students must play an active role physically, mentally, and emotionally (Yamashita, 2011). Therefore, Civic Education teachers need to be equipped with the ability to choose, to develop, and to apply multimedia in Civic Education learning to fulfil the pedagogic competence of Civic Education teachers.

\section{CONCLUSION}

Living values-based interactive multimedia for Civic Education is conceptually the integration of living values and the principles of living values education into interactive multimedia by paying attention to the principles of scientific learning, by developing Core Competencies (CC) and Basic Competencies (BC) in accordance with the 2013 curriculum and the principles of the development of interactive multimedia. The framework of living values-based interactive multimedia for Civic Education includes motivation, title, menu, $\mathrm{CC}-\mathrm{BC}$ and learning objectives, concept maps, material content with varied multimedia, videos of motivation/reflection, VCT Lists, and quizzes. Validation results show that most of the components of content, presentation, and the principles of the early product of living values-based are considered good enough. Most students respond very well to the use of interactive multimedia in Civic Education learning for character development and the effectiveness of learning in achieving the goals.

\section{Acknowledgments}

The research is a grant from the Ministry of Research, Technology, and Higher Education of Indonesia through the scheme of Postgraduates Team Research. The author would like to express sincere appreciation for all support provided. 


\section{REFERENCES}

Agnew, P. W., Kellerman, A. S., \& Meyer, J. M., (1996). Multimedia in The Classroom. Massachusetts: A Simon \& Schuster Company.

Arsyad, A. (2009). Media pembelajaran. Jakarta: PT Raja Grafindo Persada.

Borg, W. R., \& Gall, M.D., (1989). Educational Research: An Introduction (5 $\left.{ }^{\text {th }} \mathrm{ed}\right)$. New York: Longman.

Creswell, J.W. (2012). Educational Research: Planning, Conducting, And Evaluating Quantitative And Qualitative Research. Boston: Pearson Education, Inc.

Gerlach, V.S \& Ely, D.P. (1980). Teaching and Media: a Systematic Approach (2 ${ }^{\text {th }}$ ed). New Jersey: Prentice Hall

Green, T.D \& Brown, A. (2002). Multimedia Projects in the. Classroom. California: Corwin.

Hackbarth, S., (1996). The Educational Technology Handbook. Englewood Cliffs. New Jersey: Educational Technology Publications Inc.

Heinich, R., Molenda, M., Russell, J. D., \& Smaldino, S.E. (2005). Instructional Media and Technology for Learning (7th ed). New Jersey: Prentice Hall, Inc.

Hofstetter, F.T. (2001). Multimedia Literacy ( $3^{\text {th }}$ ed). New York: McGraw-Hill International Edition

Komalasari, K. (2010). Pembelajaran Kontekstual: Konsep dan Aplikasi. Bandung: Refika Aditama.

Komalasari, K. \& Saripudin, D. (2015). Integration of Anti-Corruption Education in School's Activities, American Journal of Applied Sciences, 12 (6), 445-451

Komalasari, K \& Sapriya. (2016). Living Values Education in Teaching Materials to Develop Students' Civic Disposition, The New Educational Review, 44 (2), 107-124. DOI: $10.15804 /$ tner.2016.44. 2.09.

Komalasari, K \& Saripudinn, D. (2017a). Pendidikan Karakter: Konsep dan Aplikasi Living Values Education. Bandung: Refika Aditama.

Komalasari, K \& Saripudin, D. (2017b). Value-Based Interactive Multimedia Development through Integrated Practice for the Formation of Students' Character. Turkish Online Journal of Educational Technology, 16 (4), 179-186.

Komalasari, K \& Saripudin, D. (2018). The Influence of Living Values EducationBased Civic Education Textbook on Student's Character Formation, International Journal of Instruction, 11 (1), 395-410.

Latuheru, J. D. (1988). Media Pembelajaran dalam Proses Belajar Mengajar Masa Kini. Jakarta: Departemen Pendidikan dan Kebudayaan. 
Lickona. (1991). Educating for Character (How Our Schools Can Teach Respect and Responsibility). New York: Bantam Books.

Mayer, R.E.(2009). Multimedia Learning, Yogyakarta: Pustaka Pelajar,

Megawangi, R. (2004). Pendidikan Karakter (Solusi Yang Tepat Untuk Membangun Karakter Bangsa). Jakarta: Indonesia Heritage Foundation.

Miles, M.B. \& Huberman, A.M. (2014). Qualitative Data Analysis, A Methods Sourcebook. Edition 3. USA: Sage Publications.

Ministry of National Education. (2010). Desain Induk Pendidikan Karakter, Jakarta: Kementerian Pendidikan Nasional.

Munadi, Y. (2008). Media Pembelajaran. Ciputat: Gaung Persada (GP) Press.

Munir. (2012). Multimedia Konsep dan Aplikasi dalam Pendidikan. Bandung: Alfabeta.

Priyanto, D,(2009). Pengembangan Multimedia Pembelajaran Berbasis Komputer, INSANIA, 14 (1), 92-110.

Saripudin, D. \& Komalasari, K. (2015). Living Values Education in School's Habituation Program and Its Effect on Student's Character. The New Educational Review, 39 (1), 51-62.

Sutopo, A.H., (2003). Multimedia Interaktif dengan Flash. Yogyakarta: Graha Ilmu.

Tillman, D. (2004). Living Values: Activities for Children Ages 8-14. Jakarta: PT Gramedia Widiasarana Indonesia.

Usman, N. (2002). Konteks Implementasi Berbasis Kurikulum. Jakarta: PT. Raja Grafindo Persada.

Vaughan, T. (2004). Multimedia: Making It Work (6 ${ }^{\text {th }}$ ed). New York: McGraw-Hill.

Yamashita. (2011). Media Pembelajaran. Retrieved 25 February, 2012 from http://proskripsi.blogspot.com/2011/02/ perancangan-media-pembelajaran.html. 